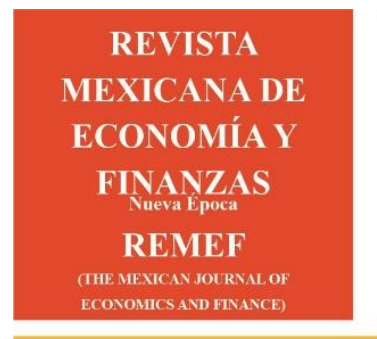

Revista Mexicana de Economía y Finanzas, Nueva Época

Volumen 15 Número 4, Octubre - Diciembre 2020, pp. $685-708$

DOI: https://doi.org/10.21919/remef.v15i4.497

(Recibido: 15/mayo/2020, aceptado: 27/agosto/2020)

Special Issue: Energy \& Growth

Guest Editor: Ilhan Ozturk, Ph.D.

\title{
Short-Term Causal Relationships between the Oil Sector and Economic Growth in the Mexican Economy: FG-ARDL Approach
}

\author{
José Eduardo Medina Reyes ${ }^{1}$ \\ Instituto Politécnico Nacional, México \\ Judith Jazmin Castro Pérez ${ }^{2}$ \\ Instituto Politécnico Nacional, México \\ Agustín Ignacio Cabrera Llanos ${ }^{3}$ \\ Instituto Politécnico Nacional, México
}

\section{Abstract}

This research aims to analyze the short-term causal relationships between the oil sector and economic growth, using two methodologies, the ARDL model and the proposal based on fuzzy logic, the FG-ARDL, Fuzzy Gaussian Autoregressive Distributed Lag. For this purpose, 59 variables of the oil sector and their relationship with the Global Economic Activity Indicator, and the corresponding indicator of primary, secondary, and tertiary activities, were analyzed in monthly format between January 1997 and December 2019. The FG-ARDL model achieved better estimates, identifying the influence of variables derived from the oil industry on economic growth with better precision. The main recommendation is to evaluate other economic relationships to verify the efficiency of the new methodology, in which the primordial limitation is its dependence to the ARDL method, so it does not provide new causal relationships. Originality was the proposed time series and fuzzy theory approach to economic modeling. The most important conclusion is that the internal consumption of fuel and PEMEX Diesel are the key variables that drive short-term economic growth, this result is better observed in the proposed model.

JEL Classification: C01, C22, O13, Q43

Keywords: Oil, Sectoral Economic Activity, Fuzzy Logic, Energy Sector

\section{Relaciones Causales de Corto plazo entre el Sector Petrolero y el Crecimiento Económico en la Economía Mexicana: Aplicación FG-ARDL}

\section{Resumen}

La presente investigación tiene como objetivo analizar las relaciones causales de corto plazo entre el sector petrolero y el crecimiento económico; utilizando dos metodologías, el modelo ARDL y la propuesta basada en lógica difusa, el Autorregresivo de Rezagos Distribuidos Gaussiano Difuso FG-ARDL. Para ello se analizaron 59 variables del sector petrolero y su relación con el Indicador Global de la Actividad Económica, y el correspondiente indicador de actividades primarias, secundarias y terciarias, en formato mensual entre enero 1997 y diciembre 2019. El modelo FG-ARDL logró mejores estimaciones, permitiendo identificar con mayor precisión la influencia de las variables derivadas de la industria petrolera en el crecimiento económico. La principal recomendación es evaluar otras relaciones económicas para verificar la eficiencia de la nueva metodología, en la que la primordial limitación es su dependencia al método ARDL, por lo que no proporciona nuevas relaciones causales. La originalidad es el desarrollo de un nuevo enfoque de series temporales y teoría difusa para el modelado económico. La conclusión más relevante es que el consumo interno de gasolina y PEMEX diésel son las principales variables que impulsan el crecimiento económico de corto plazo, resultado que se observa de mejor forma en el modelo propuesto.

Clasificación JEL: C01, C22, O13, Q4

Palabras clave: Petróleo, Actividad económica sectorial, Lógica difusa, Sector energético

${ }^{1}$ Email: humberto. eduardomedina_94@yahoo.com

${ }^{2}$ Email: Castro.410210@gmail.com

${ }^{3}$ Email: nitsuga528@gmail.com

*Sin fuente de financiamiento para el desarrollo de la investigación. 


\section{Introduction}

The energy sector has received more attention in the last decade from the government and academics interested in the economic impact of the energy industry. Currently, the remark is centered on the direct influence that oil production and its derivatives have on the performance of the growth rate of the economy. Considering that the energy industry is one of the main factors in the development of countries' economic progress, the importance of the study of this industry is to be expected, attributing this to the interaction between each one of the sectors, to mention a few: primary, industrial, manufacturing, tourism, etc.

The analysis of the impact that the energy sector has in the aggregate economic growth and the several economic sectors, is a fundamental element of a complex objective, such as, to generate economic policies by the State and business strategies of the private initiative, that allows the best performance of the sector within the economy. For the Mexican economy, the energy sector has been one of the main promoters of growth. Specifically, the behavior of the oil industry and its derivatives has been fundamental to the creation of many policies to stimulate the production growth in Mexico (Marroquín-Arreola \& RíosBolívar, 2017). The studies carried out to identify the dependence of economic growth of the oil sector is focused on the assumptions of the time series theory.

On the other hand. Tiba and Omri (2017) compiled a collection of research about economic growth and energy, focusing on three main aspects: applied econometric analysis; economic growth and the environment; and the combination of both. Time series theory is the most common methodology used to analyze economic growth and the relationship with the energy sector; some of the models that have been used include Granger Causality tests, Hsiao's version of Granger Causality, Cointegration, Vector Error Correction (VEC), Autoregressive Vector (VAR), and Autoregressive Distributed Lag (ARDL). These methodologies provide information about the causal relationships between economic growth and the energy sector.

The literature on this issue indicates that the time series theory, thus far, is the best adapted to the estimation of the causality relationship between economic variables. The ARDL model is one of the most frequently applied methods in multiple studies on the subject, primarily attributed to the fact that the model allows the estimation of economic variables that have a different order of integration; and as well, academics consider that the ARDL technique is the most appropriate technique to identify immediate impact coefficients. Therefore, the ARDL method is considered the best for short-term evaluation (Razmi et al., 2020), (Habib-ur-Rahman et al., 2020), (Nguyen and Ngoc, 2020), (Nadeem et al., 2020), (Le et al., 2020), (Koondhar et al., Kong, 2020), (Khan et al., 2020) and (Mirza \& Kanwal, 2017).

Moreover, the studies focused on an analysis according to the theory of time series that present a greater efficiency in terms of the estimation and the fulfillment of their main assumptions, highlight the methodologies that focus on cointegration as the main element of their study. Two methods stand out: the VAR and the VEC, characterized by to model the behavior of economic variables as a system that allows us to recognize the impact of the variations of one variable to another, so that we can determine if the effect generated is permanent or transitory (Bekhet et al., 2017), (Appiah, 2018), (Churchill and Ivanovski, 2019), (Khobai, 2017) and (Zhang et al., 2018).

It is important to mention that the mentioned methodologies still have problems with the errors that can increase by various limitations, such as incomplete information, small size samples, deficient causality analysis, etc. Therefore, the errors of these models must comply with the general criteria of the time series theory, such as homoscedasticity, non-serial autocorrelation, non-collinearity, etc.; assumptions that the 
techniques must comply to guarantee their efficiency and capacity to model economic events. The problem emerges from the fact that these methodologies have important restrictions that reduce their potential, causing the need to adapt to new tendencies in frontier studies, to reduce these deficiencies, guarantee reliable results (Ahmad and others, 2020), (Algarini, 2020), (Dabachi and others, 2020), (Esso and Keho, 2016), (Galadima and Aminu, 2019), (Sunde, 2020).

Returning to the main issue, the effects of the oil sector on the Mexican economy have generated several debates about their importance and influence on economic growth. For example, the decrease in oil prices in 2015 caused the Mexican government to rethink its budget plan, cause of the expected low oil revenues. Therefore, the controversy of focusing the budget base of the economy on the oil industry has been a source of analysis and discussion in the academic studies world (Antón \& Padilla, 2015) and (Miranda-Mendoza, 2015).

However, the analysis does not stop at the government sector, but rather the effect that fluctuations in the oil activity have on the entire economy, through the various petroleum derivatives. Therefore, the identification of the oil variables that motivate the growth of economic activity acquires great importance for decision making, since each economic sector, primary, secondary and tertiary activities, use hydrocarbon fuels as an energy source (Marroquín-Arreola \& Ríos-Bolívar, 2017).

Petróleos Mexicanos (PEMEX) is the main producer and distributor of crude oil, natural gas, and refined products in Mexico; therefore, this company is highly important for the Mexican economy. Thus, we must recognize that the main source of information for this research comes from this institution and, consequently, recognizes their importance for economic growth.

The present research develops an analysis of the causal relationships between short-term economic growth and the oil industry in Mexico, estimated by two methodologies, the ARDL model and our proposal the "Fuzzy Gaussian Autoregressive Distributed Lag" FG-ARDL process. The central argument is that the causal relationships between economic variables are identified more efficiently by the technique based on the fuzzy theory. The objective is to explain the impact that the different variables of the oil sector (table 1) have on the short-term economic growth; and compare the outputs of the two methodologies applied to the analysis.

The research is structured as follows; section 2, analyses the relationship between economic growth and the energy sector; section 3, presents the FG-ARDL model; and section 4, studies the short-term causal relationships between economic growth and the oil industry, as measured by two tools, the conventional ARDL model and the FG-ARDL; finally, section 5 presents the conclusions and recommendations.

\section{The linear model of causal relations: economic growth and the oil industry}

The study of the causal relationships between the oil sector and the growth of the Mexican economy is important in the context of the debate on current policies and the influence of the industry in stimulating production. In recent decades the oil industry is a focus of analysis due in part to the fluctuations in prices and the reduction of oil reserves, resulting in the modification of government plans and the adverse effects on Mexican economic activity, as occurred in 2015-2016 with the decline in the price of oil and again in 2020 with the COVID-19 crisis.

The negative effects of volatility on the oil market should be recognized, as well as the positive ones. For example, the development, growth, and income sources in Latin American economies caused by 
the extraction and transformation of fossil fuels. However, the negative effects caused by the oil industry in the recent decade present a new challenge for people involved in the industry and activities that depend on petroleum-derived energy.

The purpose of this section is to analyze the impact of the oil sector on general economic growth, presenting a linear causal model. The objective of the mentioned study is to identify the causal relationships that oil and petroleum products have on economic growth.

\subsection{Economic growth models}

The literature on economic growth models emphasizes the importance of investment, consumption, and energy production as factors in economic growth. Among the models analyzed are those by Harrod-Domar, Kaldor, Joan Robinson, Meade, and Solow.

We started with the Harrod-Domar model, which proposes a model for an advanced capitalist economy, to identify the requirements for constant economic growth. The investment plays a central role in the economic growth, from two ways, the first one related to the creation of income and the second one, concerns the increase in the productivity of the economy, that is to say, to the generation of installed capacity.

Kaldor's distribution model traces the savings-income ratio as a variable that affects the growth, based on a classical savings function, the propensity to save and invest is considered to be fundamental to generate long-term economic growth (Sala-i-Martin, 2000).

Joan Robinson builds a simple model of economic growth based on the rules of game theory for capital, that is, it considers the choice of the capital that drives the accumulation that guarantees long-term growth. The model is one in which net national income is the sum of the total wage bill plus total profits. Therefore, the economic growth of a society in the long term is directly related to the process of capital accumulation, which strongly depends on the savings-investment relationship. Then in concrete terms, it can be intuited that the productive processes that generate an increase of the capital stock are the primary source to stimulate the increase in the total product (Robinson, 1962).

Meade proposed a neoclassical model of economic growth, designed to show the simplest way for an economic system to behavior through a process of equilibrium growth. In this model, the net production return is a function of four fundamental factors:

i) The net capital stock, that is, the machinery and equipment available for production,

ii) The number of available workers,

iii) Land and natural resources,

iv) The technology, ideas, processes, and production methods that constantly motivate efficiency and productivity.

Finally, Solow's growth model postulates a continuous production function that links production to capital and labor inputs. The model points out that technical efficiency tends to denote that the capital-labor relationship is adjusted over time towards a stationary state, showing that all economies will find a point of equilibrium growth (Barro \& Sala-i-Martin, 2018). 


\subsection{Linear economic growth model}

Returning to the main idea of this section, several characteristics of growth models are recognized, starting with the fact that investment, capital, and technology play an important role in the provision of incentives towards higher productivity; secondly, productive resources and labor are identified as the factors that drive production growth; and finally, the capacity of the relationships between income, savings and investment to generate incentives for upward growth.

The analysis corresponds to the theoretical specification of growth models. On the other hand, the literature on economic growth includes the energy sector as a cause of economic growth, studies on the subject developed econometric and causal analysis of the relationships between both variables.

The main conclusions are that there is a direct relationship between economic growth and the increase in investments in the energy sector. In this context, the condition that investment is important to promote higher production is satisfied. Thus, investment in the energy sector must be specifically motivated in the oil industry (Nweze \& Edame, 2016), (Siddiqui, 2004), (Santillán-Salgado \& Venegas-Martínez, 2016), (Salazar-Núñez et al., 2020). Salazar-Núñez et al., 2020), and (Aali-Bujari, et al., 2017).

Furthermore, the impact of hydrocarbon energy consumption on economic growth in various economies is studied. The highlights of these investigations are that the consumption has a causal relationship with economic growth and is statistically significant, in other words, the increase in production is related to the consumption of gasoline, diesel and other refined products (Marroquín-Arreola \& RíosBolívar, 2017), (Solarin \& Ozturk, 2016) and (Tang et al. ,2016).

Two fundamental aspects of the research have been analyzed so far, growth models as well as the importance of investment and oil consumption in the economies. We propose a linear model to illustrate the importance of the oil industry to the Mexican economy.

$$
\Delta Y_{t}=\alpha_{0}+\alpha_{1} R N_{t}+\alpha_{2} C E_{t}+\alpha_{3} V E_{t}+\alpha_{4} X E_{t}+\alpha_{5} I E_{t}+\alpha_{6} P E_{t}+\varepsilon_{t}
$$

Equation (1) shows the linear growth model to be assessed, using an ARDL model. Where $\Delta Y_{t}$ is the production growth rate, $\alpha_{0}$ is the economic growth caused by events exogenous to the oil sector; $R N_{t}$ is the extraction of natural resources, in our study is the production or extraction of hydrocarbons; $C E_{t}$ is the energy consumption in the economy, measured through domestic oil sales; $V E_{t}$ represents the income from the sale of energy in the economy, studied through the value of domestic sales of oil-based energy; $X E_{t}$ is the export of oil and petroleum products, measured through exports to various international markets; $I E_{t}$ is imports of energy, in our study they are to be analyzed with the import of refined products; $P E_{t}$ presents the price of oil and petroleum derivatives, is measured by the previous monthly average; and $\alpha_{i}$ represent the $i$ parameters implemented in the linear model that indicate the impact of energy sector variables on the growth rate of the economy.

\section{Model FG-ARDL}

This section introduces a new methodology for causality analysis on economic variables, called "Fuzzy Gaussian Autoregressive Distributed Lag" (FG-ARDL). The main characteristic of the model is to establish a transformation in the estimation methodology of the conventional ARDL model. 
Assumption 1. The causal relationships between $y_{t}$ and $x_{t}$ has a membership function $\mu_{t}\left(x_{t} \rightarrow y_{t}\right)$, so that $y_{t}=\mu_{t}\left(\alpha_{i} x_{t}\right)$. But we know that $x_{t}$ and $y_{t}$ are crisp sets, therefore, the FG-ARDL model is

$$
y_{t}=\mu_{t}\left(\alpha_{i}\right) x_{t}+\varepsilon_{t}
$$

where $y_{t}$ is the dependent variable, $x_{t}$ the explicative variable, $\mu_{t}\left(\alpha_{i}\right)$ represents the fuzzy dependency parameter and $\varepsilon_{t}$ are white noise errors. Equation (2) describes the corresponding formula for the proposed model, identifying that the causal relationship between economic variables has a membership function that captures the level of impact that a variable has on another variable.

Assumption 2. There is a parameter $\alpha_{i}^{*}$ in $\mu_{t}\left(\alpha_{i}\right)$, such that, provide the min $\left(\varepsilon_{t}\right)$ of the errors generated by this process are minimal. Thus, the causal relationship between the analyzed variables is better captured. So, they say that $\hat{y}_{t}$ the estimate is a crisp set, when $\varepsilon_{t}$ has the minimum value provided by equation (2).

$$
\begin{gathered}
\varepsilon_{t}=\frac{\sum_{i=1}^{n}\left|y_{t}-\hat{y}_{t}\right|}{n}=M A D \\
\text { and } \\
\mu_{t}\left(\alpha_{i k}\right)=e^{-\left(\frac{\alpha_{i k}-\alpha_{i}}{\delta \alpha_{i}}\right)^{2}}
\end{gathered}
$$

where (4) represents the membership function of the Gaussian parameter associated with the $x_{t} ; \alpha_{i}$ is the mean coefficient, estimated using the traditional ARDL model; $\alpha_{i k}$ are the parameters that are distributed along the curve in figure 1; and $\delta_{\alpha_{i}}$ represents the width of the Gaussian curve. Figure 1 is the graphical representation of the Gaussian membership function for the fuzzy dependency coefficient for $x_{t}$. And the equation (3) is the Mean Absolute Deviation (MAD), where the dividend is the sum of the mean absolute error, divided by the $n$ observations.

Assumption one shows the existence of a membership function in the causal parameters, whereby the alpha coefficient oscillates around the Gaussian function. Once this behavior has been identified, assumption 2 mentions that inside the Gaussian membership function for the alpha parameter exists a coefficient, such that it satisfies the criterion of the minimal error.

In other words, the method for carrying out the translation of fuzzy coefficients into crisp parameters is through the application of error minimization. This is achieved by initially selecting the size of the membership function, the width, and then identifying the value around the Gaussian function that satisfies the minimum error condition. Consequently, the Gaussian membership function can take positive and negative values; then, there is the possibility of movements in the causality of the impact coefficients, increasing or decreasing the impact of the independent variables on the dependent variable. 


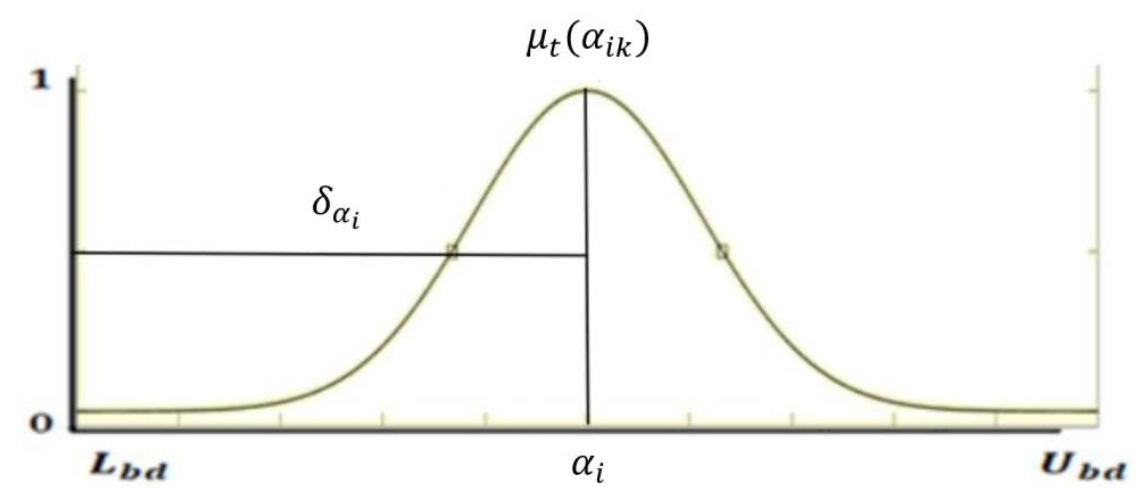

Figure 1. Gaussian membership function of the causality parameter.

Source: Own elaboration.

Thus, if the errors are measured through the mean absolute deviation, the parameter $\alpha_{i}^{*}$ is found by solving the next linear optimization problem:

$$
\begin{gathered}
\min \varepsilon_{t} \\
\text { Subject to } \\
\delta_{\alpha_{i}}<0 \\
\alpha_{i k} \in \mathbb{R}
\end{gathered}
$$

where the width of the curve $\delta_{\alpha_{i}}$ must be strictly positive and the parameters $\alpha_{i k}$ on the curve must belong to the real number. Therefore, resolving (5) has that the optimal FG-ARDL estimation is expressed as follows:

$$
y_{t}^{*}=\alpha_{i}^{*} x_{t}+\varepsilon_{t}
$$

We understand that $y_{t}^{*}$ is the crisp forecast, $\alpha_{i}^{*}$ is the crisp parameter that resolves (5). The steps for estimating FG-ARDL are described below:

Step 1: Estimate the ARDL model, following the criteria of time series theory.

Step 2: Save the parameters of the conventional ARDL model and use them as the mean value for the Gaussian membership function (4).

Step 3: Minimize (5) through equation (2) and using the membership function (4). This step is fundamental in the process, the process consists in the programming of equation (2); where the parameters have a membership function (4) assuming as mean value the parameters of the traditional ARDL and an arbitrary width of the curve; then calculate the error (mean absolute deviation); finally, minimize the errors by modifying the width of the membership function and taking different values along the curve until we find the coefficient that guarantees the minimum error.

Step 4: Save the results of step 3 and interpret the parameters. 


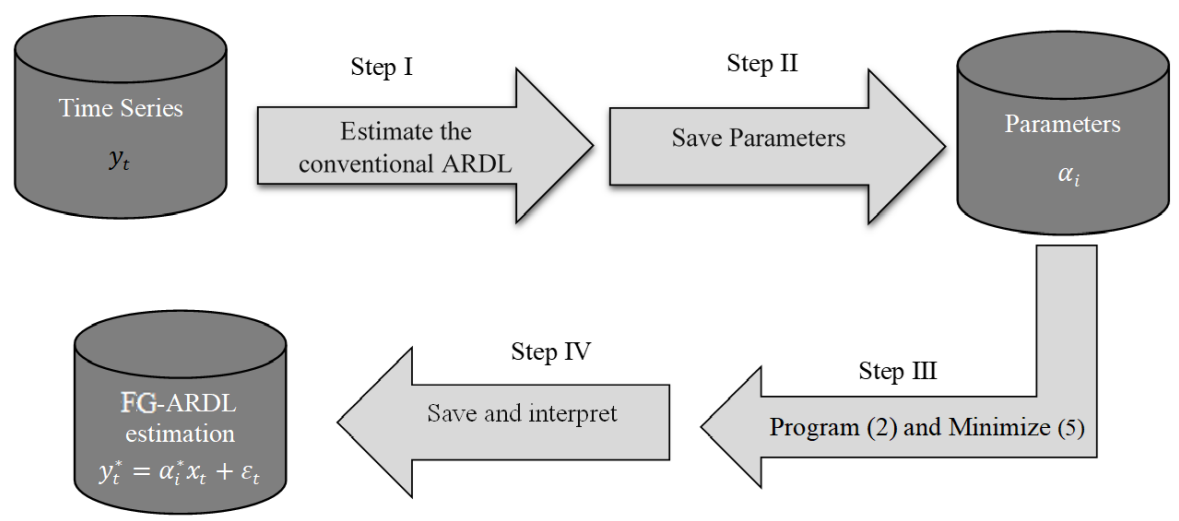

Figure 2. FG-ARDL model process Source: Own elaboration.

Rethinking the linear economic growth model (1) under the fuzzy theory approach, the coefficients associated with the model have membership functions that measure the degree of causality of the independent variable in the time series analyzed. Therefore, the model is reformulated in the following way:

$$
\begin{gathered}
\Delta Y_{t}=\alpha_{0}+\mu_{t}\left(\alpha_{1 k}\right) R N_{t}+\mu_{t}\left(\alpha_{2 k}\right) C E_{t}+\mu_{t}\left(\alpha_{3 k}\right) V E_{t}+\mu_{t}\left(\alpha_{4 k}\right) X E_{t}+\mu_{t}\left(\alpha_{5 k}\right) I E_{t}+ \\
\mu_{t}\left(\alpha_{6 k}\right) P E_{t}+\varepsilon_{t}
\end{gathered}
$$

The only difference between (7) and (1) is the linear estimation model. Therefore, the next section will evaluate the two methodologies suggested for estimating the short-term relationships of economic growth and the oil industry.

The parameters of the FG-ARDL model are a product of ARDL methodology, so the fuzzy coefficients satisfy the criterion of having a value different to zero, in other words, the level of statistical significance is the same in the fuzzy parameter as in the estimation of the ARDL model. Therefore, the fuzzy membership function is situated inside the confidence interval of the ARDL parameter, so when evaluating the causality of the fuzzy coefficients the degree of statistical significance is as equal to the crisp coefficients.

\section{A study of the Mexican economy}

The objective of this research is to explain the impact of the various variables of the petroleum sector (table 1) on short-term economic growth, which is measured by the Global Economic Activity Indicator and to compare the results of the estimation of the conventional ARDL and FG-ARDL models. Therefore, this section develops the empirical application of the models to assess causality among the economic variables in table 1 .

Table 1 shows the variables analyzed to respond to the linear model hypothesis presented in the second section. The codification is developed in two ways, the explicative variables are presented with acronyms, for example, the Global Economic Activity Indicator is represented as IGAE, the indicator for primary activities as PA-IGAE, in the case of secondary activities SA-IGAE, and the Tertiary Activity Indicator is the TA-IGAE. On the other hand, the independent variables are listed from $\boldsymbol{x}_{\mathbf{1}}$ up to $\boldsymbol{x}_{57}$ (more 
detail of each variable, see table 1), these variables correspond to each of the variables presented in the linear economic growth model (1) of energy, specifically in the case of the $\boldsymbol{Y}_{\mathbf{5}}$ global indicator of economic activity in the energy sector is incorporated in the analysis as an independent variable. Overall, we analyzed 58 explanatory and 4 response variables, in the period January 1, 1997, to December 2019, monthly.

First, the analysis of unit roots test was carried out, table A7, where we emphasize that the variables have a different order of integration. The explainable variables are stationary in the first difference, the independent variables meet the criterion of stationary in three different orders, levels, first order, and second order. The analysis was carried out using the KPSS stationary test to identify the specific order of integration of each variable (see table A7). The above result is one of the main conditions that the ARDL model.

Figure 3 shows the behavior of the four economic activity indicators used to study the growth rate of economic activity in the short term for the Mexican economy. The IGAE indicates a growth trend with a strong impact on the seasonal component and a structural break in 2009; a high variability in behavior can be observed in the case of PA-IGAE, note that primary activities are highly volatile, with a trend that is increasing but less marked than in the Global Economic Activity Indicator. The SA-IGAE indicates an upward long-term trend; however, in the last periods of analysis the trend is horizontal, and this situation suggests that there is a high level of uncertainty in the secondary market. Finally, the tertiary activities show a strong upward trend, both in the short-term and in the long-term, and the growth of the tertiary sector is identified as very important for this research.

The results shown by the variables estimated for the behavior of the economy, in general, are in table 2, firstly that the Global Economic Activity Indicator, as measured by the IGAE variable, is represented in the study until the second lag. In other words, the present value of the economic activity is influenced by the last two values of its past, considering that the information is monthly, then, the last immediate previous bimester turns out to be relevant to explain the current behavior of the activity in the economy.

Secondly, another observable fact is that the sign that the coefficient maintains is negative, meaning that the relationship of the economic activity with its history is inversely proportional, as this type of series is considerably affected by the seasonal component. That is the reason why the result obtained by the FGARDL method is considered even better, because, although the value of the coefficient recognizes the influence of seasonality in the time series; the effect is smaller compared to the traditional ARDL model. The variables $x_{5 t}$ and $x_{6 t}$ refer to the Total light crude oil production and Total superlight crude oil production, respectively, both present relations that are inversely proportional to the behavior of the aggregate economic activity, that means that with decreases in total production of both types of crude oil, the present value of economic activity increases, alternately; however, both models refer to a relatively low impact coefficient, even the fuzzy model suggests that the effect is less than estimated by conventional ARDL.

Table 1. Selected variables of the Mexican economy

\begin{tabular}{|c|c|c|}
\hline Variables & Variables & Variables \\
\hline $\begin{array}{l}\text { IGAE: Global Economic Activity } \\
\text { Indicator }\end{array}$ & $\begin{array}{l}x_{17 t}: \text { Volume of total domestic sales } \\
\text { of liquefied gas }{ }^{(1)}\end{array}$ & $\begin{array}{l}x_{38 t}: \text { Volume of total crude oil } \\
\text { exports American region }{ }^{(1)}\end{array}$ \\
\hline $\begin{array}{l}\text { PA-IGAE: Primary Activities } \\
\text { Global Economic Activity } \\
\text { Indicator }\end{array}$ & $\begin{array}{l}x_{18 t}: \text { Volume of total domestic sales } \\
\text { of Pemex diesel }{ }^{(1)}\end{array}$ & $\begin{array}{l}x_{39 t}: \text { Volume of total crude oil } \\
\text { exports American region }{ }^{(4)}\end{array}$ \\
\hline
\end{tabular}




\begin{tabular}{|c|c|c|}
\hline $\begin{array}{l}\text { SA-IGAE: Secondary Activities } \\
\text { Global Economic Activity } \\
\text { Indicator }\end{array}$ & $\begin{array}{l}x_{19 t}: \text { Volume of total domestic sales } \\
\text { of desulphurized diesel }^{(1)}\end{array}$ & $\begin{array}{l}x_{40 t}: \text { Average price of total crude oil } \\
\text { exports American region }{ }^{(5)}\end{array}$ \\
\hline $\begin{array}{lrr}\text { SA-IGAE: } & \text { Tertiary } & \text { Activities } \\
\text { Global } & \text { Economic } & \text { Activity } \\
\text { Indicator } & & \end{array}$ & $\begin{array}{l}x_{20 t}: \text { Volume of total domestic sales } \\
\text { of fuel oil }{ }^{(1)}\end{array}$ & $\begin{array}{l}x_{41 t}: \text { Volume of total crude oil } \\
\text { exports Europe region }{ }^{(1)}\end{array}$ \\
\hline $\begin{array}{l}Y_{5 t}: \text { Energy Global Economic } \\
\text { Activity Indicator }\end{array}$ & $\begin{array}{l}x_{21 t}: \text { Volume of total domestic sales } \\
\text { of asphalt }\end{array}$ & $\begin{array}{l}x_{42 t}: \text { Value of total crude oil exports } \\
\text { Europe region }\end{array}$ \\
\hline $\begin{array}{l}\boldsymbol{x}_{\mathbf{1}}: \text { Total liquid hydrocarbons } \\
\text { production }^{(1)}\end{array}$ & $\begin{array}{l}x_{22 t}: \text { Volume of total domestic sales } \\
\text { of other oil products }{ }^{(1)}\end{array}$ & $\begin{array}{l}x_{43 t}: \text { Average price of total crude oil } \\
\text { exports Europe region }\end{array}$ \\
\hline $\boldsymbol{x}_{2 \boldsymbol{t}}:$ Total gas production ${ }^{(1)}$ & $\begin{array}{l}x_{23 t}: \text { Value of domestic sales of } \\
\text { natural gas }{ }^{(3)}\end{array}$ & $\begin{array}{l}x_{44 t}: \text { Volume of total exports of } \\
\text { petroleum products }(1)\end{array}$ \\
\hline $\boldsymbol{x}_{3 t}:$ Total crude oil production ${ }^{(1)}$ & $\begin{array}{l}x_{24 t}: \text { Value of domestic sales of } \\
\text { petroleum products }{ }^{(3)}\end{array}$ & total gasoline exports \\
\hline $\begin{array}{l}x_{4 t}: \text { Total heavy crude oil } \\
\text { production }^{(1)}\end{array}$ & $\begin{array}{l}x_{25 t}: \text { Value of domestic sales of } \\
\text { liquefied gas }{ }^{(3)}\end{array}$ & $\begin{array}{l}x_{46 t}: \text { Volume of exports of other oil } \\
\text { products }{ }^{(1)}\end{array}$ \\
\hline $\begin{array}{l}\boldsymbol{x}_{5 t} \text { : Total light crude oil production } \\
\text { (1) }\end{array}$ & $\begin{array}{l}x_{26 t}: \text { Value of domestic sales of } \\
\text { Pemex diesel }{ }^{(3)}\end{array}$ & $\begin{array}{l}x_{47 t}: \text { Volume of petrochemical } \\
\text { exports }{ }^{(6)}\end{array}$ \\
\hline $\begin{array}{l}x_{6 t}: \text { Total superlight crude oil } \\
\text { production }{ }^{(1)}\end{array}$ & $\begin{array}{l}x_{27 t}: \text { Value of domestic sales of } \\
\text { desulfurized diesel }{ }^{(3)}\end{array}$ & $\begin{array}{l}x_{48 t}: \text { Value of petrochemical e } \\
\text { (4) }\end{array}$ \\
\hline $\begin{array}{l}\boldsymbol{x}_{7 t}: \text { Total crude oil production in } \\
\text { marine regions }\end{array}$ & $\begin{array}{l}x_{28 t}: \text { Value of domestic fuel oil sales } \\
(3)\end{array}$ & $\begin{array}{l}x_{49 t}: \text { Volume of imports of petroleum } \\
\text { products }{ }^{(1)}\end{array}$ \\
\hline $\begin{array}{l}x_{8 t}: \text { Total Southern Region Crude } \\
\text { Oil Production }{ }^{(1)}\end{array}$ & $\begin{array}{l}x_{29 t}: \text { Value of domestic sales of } \\
\text { asphalt (3) }\end{array}$ & $\begin{array}{l}x_{50 t}: \text { Vol } \\
(1)\end{array}$ \\
\hline $\begin{array}{l}\boldsymbol{x}_{\boldsymbol{9} \boldsymbol{t}}: \text { Total Northern Region Crude } \\
\text { Oil Production }\end{array}$ & $\begin{array}{l}x_{30 t}: \text { Value of domestic sales of other } \\
\text { petroleum products }{ }^{(3)}\end{array}$ & $x_{51 t}: V_{0}$ \\
\hline $\begin{array}{l}\boldsymbol{x}_{\mathbf{1 0}} \text { : Total natural gas production } \\
\text { (2) }\end{array}$ & $\begin{array}{l}x_{31 t}: \text { Volume of total crude oil exports } \\
\text { by type }{ }^{(1)}\end{array}$ & $x_{52 t}:$ Volume of \\
\hline $\begin{array}{l}\boldsymbol{x}_{11 t} \text { : Total production of non- } \\
\text { associated natural gas }{ }^{(2)}\end{array}$ & $\begin{array}{l}x_{32 t}: \text { Value of total crude oil exports } \\
(4)\end{array}$ & $x_{53 t}:$ Volume of fuel oil imports ${ }^{(1)}$ \\
\hline $\begin{array}{l}\boldsymbol{x}_{\mathbf{1 2 t}} \text { : Total natural gas production } \\
\text { in marine regions }\end{array}$ & $\begin{array}{l}x_{33 t}: \text { Average price of total crude oil } \\
\text { exports }{ }^{(5)}\end{array}$ & $x_{54 t}:$ Volume of $\mathrm{n}$ \\
\hline $\begin{array}{l}\boldsymbol{x}_{\mathbf{1 3 t}} \text { : Total South Region Natural } \\
\text { Gas Production (2) }\end{array}$ & $\begin{array}{l}x_{34 t}: \text { Volume of total Mayan crude oil } \\
\text { exports }{ }^{(1)}\end{array}$ & $x_{55 t}: \mathrm{L}$ \\
\hline $\begin{array}{l}\boldsymbol{x}_{\mathbf{1 4 t}}: \text { Total Northern Region } \\
\text { Natural Gas Production }^{(2)}\end{array}$ & $\begin{array}{l}x_{35 t}: \text { Value of total Mayan crude oil } \\
\text { exports }{ }^{(4)}\end{array}$ & $x_{56 t}:$ Turb \\
\hline $\begin{array}{l}\boldsymbol{x}_{\mathbf{1 5 t}}: \text { Volume domestic natural gas } \\
\text { sales }\end{array}$ & $\begin{array}{l}x_{36 t}: \text { Average price of total Mayan } \\
\text { crude oil exports }{ }^{(5)}\end{array}$ & prite \\
\hline $\begin{array}{l}x_{16 t}: \text { The volume of total domestic } \\
\text { sales of petroleum products }{ }^{(1)}\end{array}$ & $\begin{array}{l}x_{37 t}: \text { Average price of total crude oil } \\
\text { exports }{ }^{(5)}\end{array}$ & \\
\hline
\end{tabular}

Source: own elaboration with data from INEGI.

In turn, total natural gas production in marine regions, variable $x_{12 t}$, the relationship is directly proportional to the economic activity, although the coefficient suggested by the FG-ARDL is considerably 
lower than that estimated by the traditional model, arguably, by increasing the total south region natural gas production is possible to obtain an increment in the aggregate value of the economy.

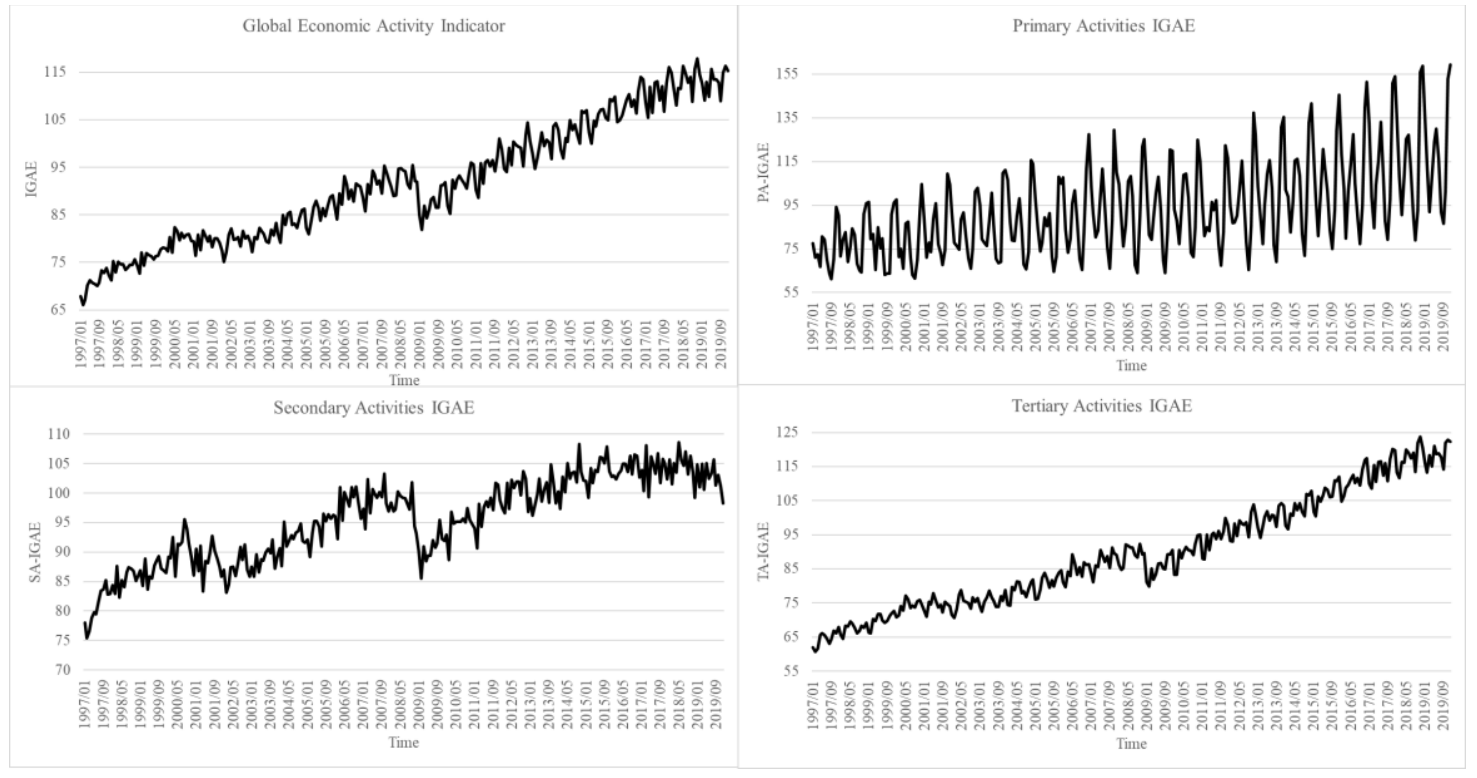

Figure 3. Dependent variables

Source: Own elaboration in Excel with data from INEGI.

Volume domestic natural gas sales, the volume of total domestic sales of petroleum products, and volume of total domestic sales of PEMEX diesel, variables $x_{15 t}, x_{16 t} \mathrm{y} x_{18 t}$, correspondingly, positive signs in the study, this means that an increase in sales of the above-mentioned products is translated into economic growth, this is consistent with the fact that in the presence of increases in national energy consumption, the economy increases productive activity. There is one important element to highlight, FGARDL suggests that domestic sales of PEMEX diesel have the greatest impact on the benefits to the aggregate economy, while the ARDL estimates that the greatest positive effect is generated by domestic sales of oil products, whereas PEMEX diesel is an oil product, It is consistent for both models to highlight the relevance of the variables in the estimation, However, there is evidence that the diffuse model presents a better fit, to the extent that it identifies that of the variety of oil products consumed nationally, Pemex diesel is the product that is relevant in the economic growth of the country.

On the other hand, variables $x_{20 t}$ and $x_{22 t}$ refer to the volume of total domestic sales of fuel oil and volume of total domestic sales of other oil products, respectively; variables that are inversely related to the behavior of short-term productive activity in the economy, that is, if there is a decrease in domestic sales, or domestic consumption of both products, the economic activity increases, and vice-versa. Although the impact on the economy generated by movements in these two variables is relatively small, as measured by their estimation coefficients.

For the variables $x_{24 t}$ and $x_{29 t}$ that relate to the value of domestic sales of petroleum products and value of domestic sales of asphalt, the present relationship for activity in the economy is direct, this means that with increases in these variables, economic growth occurs, the two models suggest that the impact coefficient is considerably low and even the fuzzy model refers to a lower valuation for the parameters of both variables. 
Table 2. Estimated parameters for the Global Economic Activity Indicator

\begin{tabular}{|c|c|c|}
\hline \multicolumn{3}{|c|}{ IGAE } \\
\hline $\begin{array}{l}\text { Ln(independent } \\
\text { variable) }\end{array}$ & $\begin{array}{c}\text { ARDL } \\
\text { parameter }\end{array}$ & $\begin{array}{l}\text { FG-ARDL }^{\circ} \\
\text { parameter }\end{array}$ \\
\hline IGAE (-2) & $-0.141244 * * *$ & $-0.128307 * * *$ \\
\hline$x_{5 t}$ & $-0.084834 * *$ & $-0.032353 * *$ \\
\hline$x_{6 t}$ & $-0.046355^{* *}$ & $-0.026142 * *$ \\
\hline$x_{12 t}$ & $0.123429 * * *$ & $0.067397 * * *$ \\
\hline$x_{15 t}$ & $0.074708 * *$ & $0.042952 * *$ \\
\hline$x_{16 t}$ & $0.200713 * * *$ & $0.067968 * * *$ \\
\hline$x_{18 t}$ & $0.064718 * * *$ & $0.222728 * * *$ \\
\hline$x_{20 t}$ & $-0.048944 * * *$ & $-0.029605 * * *$ \\
\hline$x_{22 t}$ & $-0.012248 * *$ & $-0.007865^{* *}$ \\
\hline$x_{24 t}$ & $0.155817 * * *$ & $0.117299 * * *$ \\
\hline$x_{29 t}$ & $0.015596^{* *}$ & $0.015541 * *$ \\
\hline$x_{32 t}$ & $0.019470 * *$ & $0.019474 * *$ \\
\hline$x_{48 t}$ & $0.000284 * * *$ & $0.000276^{* * *}$ \\
\hline$x_{50 t}$ & $-0.010441 * * *$ & $-0.01043 * * *$ \\
\hline$Y_{5 t}$ & $0.202793 * * *$ & $0.198484 * * *$ \\
\hline $\begin{array}{l}\text { Note: Statistically sign } \\
{ }^{\circ} \text { Fuzzy coefficients h } \\
\text { coefficients. }\end{array}$ & $\begin{array}{l}\text { t at } 99 \%(* * *), 95 \% \\
\text { same level of stati }\end{array}$ & $\begin{array}{l}\text { and } 90 \%(*) \text {. } \\
\text { l significance as crisp }\end{array}$ \\
\hline
\end{tabular}

Source: Own elaboration in Excel and Eviews with data from INEGI.

Value of total crude oil exports and petrochemical exports, $x_{32 t}$ and $x_{48 t}$, respectively, have a direct relationship with economic activity, then, an increase in any one of these variables results in an aggregate effect of economic growth, otherwise, there is a decrease in the short-term growth rate of the economy; both models estimate that the impact generated by these time series is significantly low.

The volume of liquefied gas imports, $x_{50 t}$, is inversely proportional to the increase in productive activity in the economy, that is, a decrease in liquefied gas imports translates into economic growth, this is consistent from a trade balance point of view, although note that again the FG-ARDL suggests that the impact of movements on this variable is less than estimated by the conventional model.

Finally, $y_{5 t}$, which refers to the Global Economic Activity Indicator in the energy sector for domestic consumption, presents a direct relationship and also a coefficient with a value higher than almost all the estimated impacts by the other variables. This result suggests that not only the increases in local energy consumption cause increases in the country's economic activity but also that this sector is one of the most relevant in Mexico's economic growth.

Figure 4 shows the estimation of the IGAE using the FG-ARDL model, in this case, we can observe with the red line the estimated values and the black line the real value of the time series, note that the estimation of the Global Economic Activity Indicator by the proposed model is better than the results of the ARDL model. The FG-ARDL achieves a better approach to the variations and trend of the variable studied, conclusions that are supported by various indicators of model efficiency (see table 6). A total of 5 
tests were carried out on the errors of both models and the values obtained indicate that the proposed methodology is the most appropriate for modeling the behavior of the variable described.

The next model (table 3) is about the Primary Activities Global Economic Activity Indicator. The results suggest that, within this, the history of this sector is represented in the study, for both the first and the second lags, turned out to be significant. In other words, the present value of the economic activity is influenced by the last two data of the past, however, we observe that the first lag maintains a positive relationship and the second lag a negative one, this indicates that the last immediate previous value presents a directly proportional behavior. Therefore, if there is an increase in the immediately previous value as this corresponds to an increase in the variability of the primary activities in the economy, and vice-versa; in the case of the second immediate previous value, since the relationship is inversely proportional if there is growth in the primary sector, a decrease in the present value of the primary economic activity is expected.

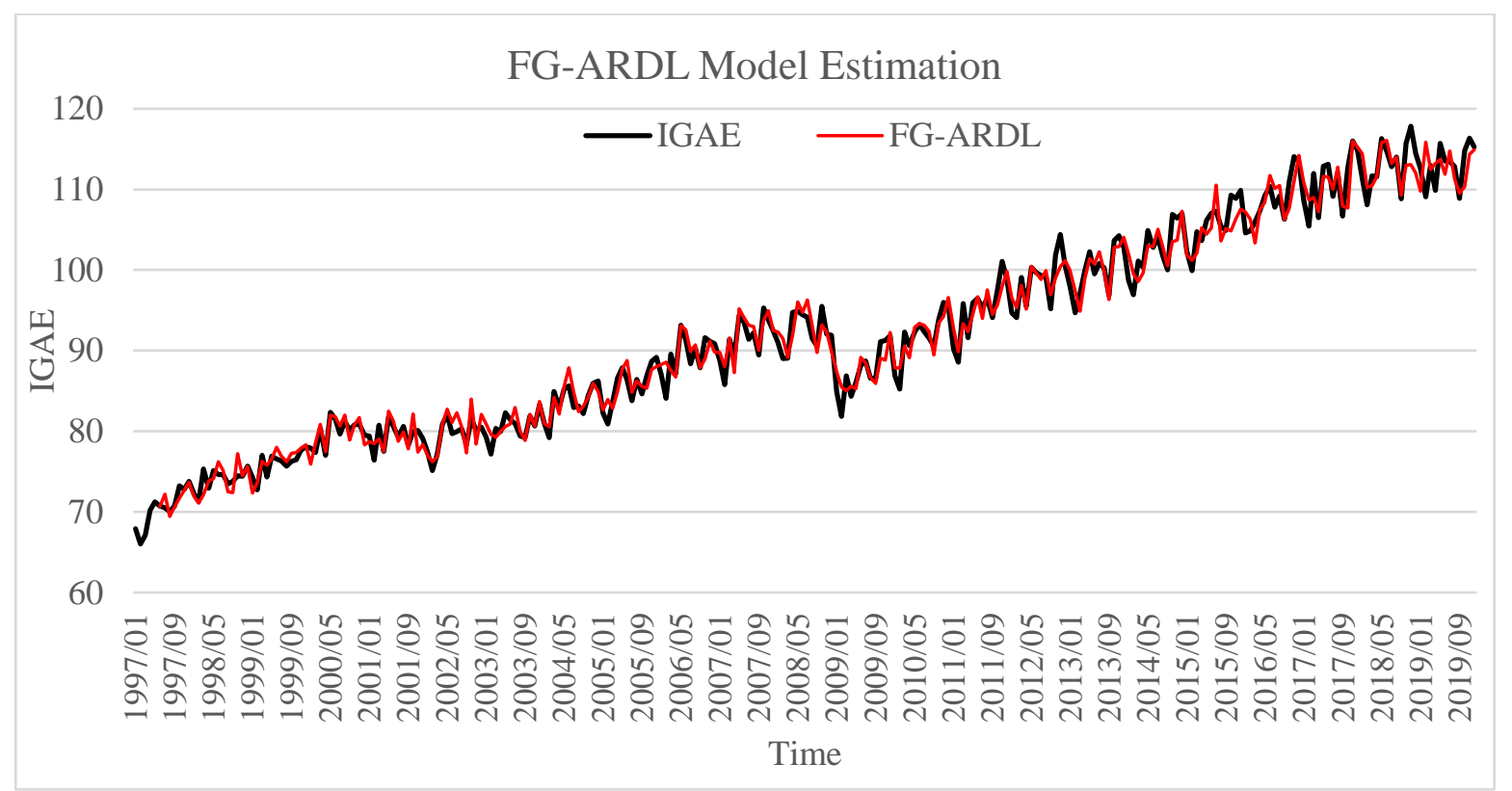

Figure 4. FG-ARDL model estimation for the Global Economic Activity Indicator Source: Own elaboration in Excel and Eviews with data from INEGI.

The above is explained by the nature of this time series, as expected to be considerably affected by the cyclical component. Another observable fact is that the FG-ARDL estimation indicates that the effect is greater than suggested by the traditional model, so it is important to take into account that the first two months of the past of the variable are relevant in the study of the economic behavior of the primary sector.

The volume of total domestic sales of liquefied gas, $x_{17 t}$, present a directly proportional relationship for the economic behavior in primary activities, is expected to have the greatest effect in the study. Since this is one of the oil sub-products that in recent years has shown the greatest growth, mainly because of its use as an alternative combustible in cargo transportation, globally is considered that this offers an important area of opportunity in terms of the positive impulse of economic activity. This is no different in Mexico since the analysis shows that in the presence of increases in national consumption of liquefied gas, economic growth is expected in the primary sector 
For the variable $x_{19 t}$, the volume of total domestic sales of desulphurized diesel, the relationship with the primary activity IGAE is inversely proportional, which means that any increase in domestic consumption of desulphurized diesel translates into a decrease in the short-term growth rate of the primary economic sector.

Table 3. Estimated parameters for the Primary Activities IGAE

\begin{tabular}{|c|c|c|}
\hline \multicolumn{3}{|c|}{ PA-IGAE } \\
\hline $\begin{array}{l}\text { Ln(independent } \\
\text { variable) }\end{array}$ & $\begin{array}{c}\text { ARDL } \\
\text { parameter }\end{array}$ & $\begin{array}{l}\text { FG-ARDL }^{\circ} \\
\text { parameter }\end{array}$ \\
\hline PA-IGAE (-1) & $0.305988 * * *$ & $0.375674 * * *$ \\
\hline PA-IGAE (-2) & $-0.485198 * * *$ & $-0.567428 * * *$ \\
\hline$x_{17 t}$ & $0.732715 * * *$ & $0.885272 * * *$ \\
\hline$x_{19 t}$ & $-0.250337 * *$ & $-0.271214 * *$ \\
\hline$x_{23 t}$ & $0.144645^{*}$ & $0.178666^{*}$ \\
\hline$x_{24 t}$ & $-0.643300 * * *$ & $-0.664903 * * *$ \\
\hline$x_{26 t}$ & $0.550661 * * *$ & $0.548218 * * *$ \\
\hline
\end{tabular}

Source: Own elaboration in Excel and Eviews with data from INEGI.

The volatility of the secondary sector makes an accurate fit to the sector's behavior more complicated. This statement can be seen in figure 5, the red line is the model fit and the black line is the PA-IGAE, the high variability of this time series causes overestimation. table 6 does not indicate the model that best describes the conditions of the primary sector. In the first place, three tests indicate that the best model is the FG-ARDL and two tests show the ARDL estimation to be the best, and the parameters of the explanatory variables are not greatly altered, such as is the case with the other estimated equations.

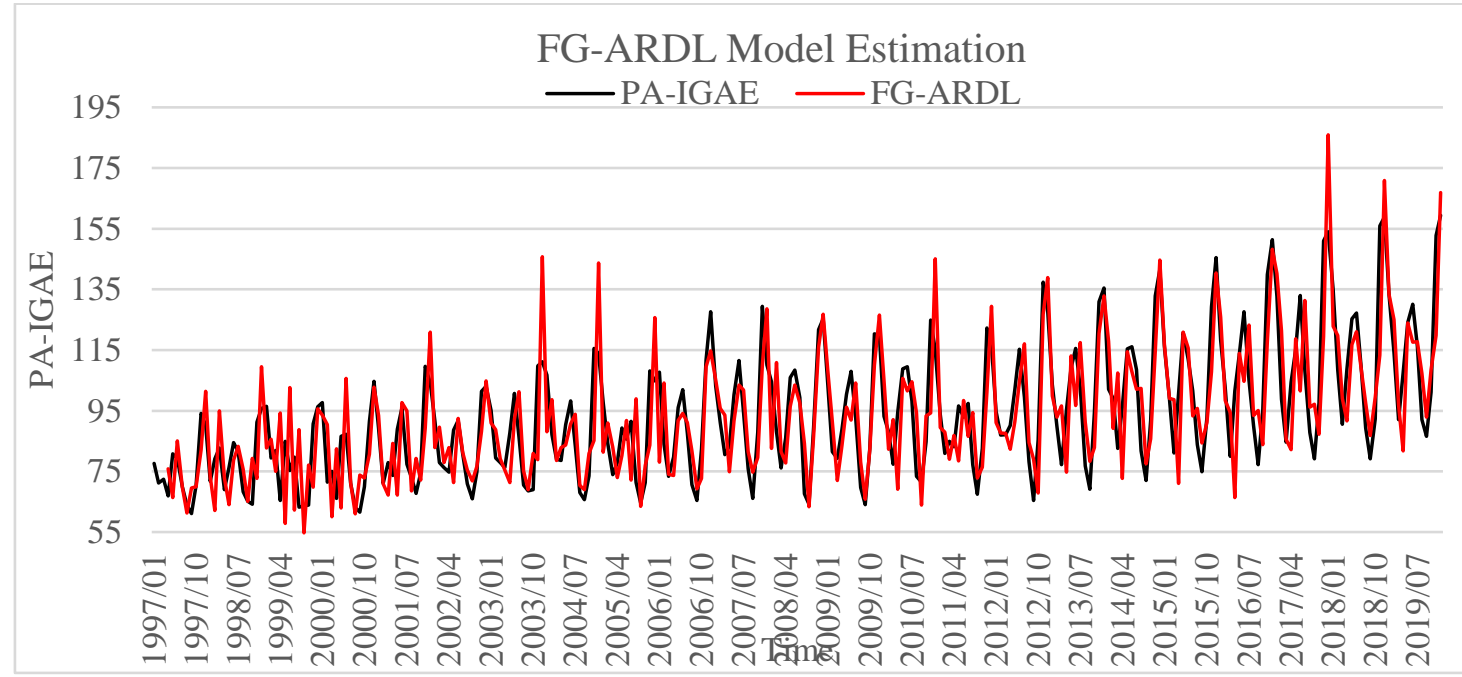

Figure 5. FG-ARDL model estimation for the Primary Activities IGAE Source: Own elaboration in Excel and Eviews with data from INEGI. 
The results for the secondary sector (table 4) indicates that exists a positive relationship with the second lag, the current behavior of SA-IGAE depends on the growth two months before, in economic terms, the installed capacity of the economy in the industry can support the growth up to two months; this result is consistent for the two methodologies implemented, noting that the FG-ARDL indicates that the impact of the sector's capacity is greater than that of the ARDL.

The impact that the energy sector $Y_{5}$ has, in general, is directly proportional to the economic growth of the secondary economic activity, the central hypothesis of the linear model for this sector is satisfied, and for the models, the FG-ARDL methodology shows that this impact is lower, the associated parameter is 0.36, compared to the ARDL model (coefficient with a value of 0.40 ).

The volume of total domestic sales of Pemex diesel, $x_{18 t}$, the value of domestic sales of desulfurized diesel $x_{27 t}$, and volume of total crude oil exports American region, $x_{39 t}$, indicate a direct relationship with economic growth, diesel sales is the variable that has the greatest impact on this sector. In this case, the FG-ARDL model shows that the impact of diesel is greater than the ARDL model indicates, in the case of the exports in the fuzzy model indicates a greater relationship than the conventional model, however, the change in the coefficient is less than the variations of other variables. The volume of diesel imports $x_{51 t}$ is inversely proportional to the economic growth of the secondary sector, as this variable is expected to negatively affect economic activity, and specifically for the Mexican economy, the causal relationship is low, a situation that can be observed through the coefficients of both models.

Table 4. Estimated parameters for the Secondary Activities IGAE

\begin{tabular}{|c|c|c|}
\hline \multicolumn{3}{|c|}{ SA-IGAE } \\
\hline $\begin{array}{l}\text { Ln(independent } \\
\text { variable) }\end{array}$ & $\begin{array}{c}\text { ARDL } \\
\text { parameter }\end{array}$ & $\begin{array}{l}\text { FG-ARDL }^{\circ} \\
\text { parameter }\end{array}$ \\
\hline SA-IGAE (-2) & $0.143809 * * *$ & $0.171033 * * *$ \\
\hline$Y_{5 t}$ & $0.403406^{* * *}$ & $0.365250 * * *$ \\
\hline$x_{7 t}$ & $0.195117 * * *$ & $0.212549 * * *$ \\
\hline$x_{18 t}$ & $0.101120 * * *$ & $0.162825 * * *$ \\
\hline$x_{27 t}$ & $0.039437 * * *$ & $0.037458 * * *$ \\
\hline$x_{39 t}$ & $0.025006^{* *}$ & $0.028185^{* *}$ \\
\hline$x_{51 t}$ & $-0.000132 * *$ & $-0.000109 * * *$ \\
\hline \multicolumn{3}{|c|}{$\begin{array}{l}\text { Note: Statistically significant at } 99 \%(* * *), 95 \%(* *) \text { and } 90 \%(*) \text {. } \\
{ }^{\circ} \text { Fuzzy coefficients have the same level of statistical significance } \\
\text { as crisp coefficients. }\end{array}$} \\
\hline
\end{tabular}

Figure 6 shows the estimate of economic growth in the secondary sector of the FG-ARDL model in line red, and the black line, the economic activity indicator value. Table 6 shows that for the SA-IGAE equation the best model is the FG-ARDL, the five tests on errors indicate that the fuzzy model is the appropriate one for the analysis.

The tertiary sector of the Mexican economy is analyzed in table 5, and the short-term relationships between the variables of the oil industry and the service activity in Mexico are presented. The results show a large improvement in terms of error reduction by the model based on a fuzzy theory for traditional ARDL methodology, in table 6 can be seen that the random variable $\varepsilon_{t}$ behaves approximately like a normal distribution and the model efficiency indicators are better than the conventional method. Thus, the methodology proposed to study the causality between economic variables has been significantly improved. 
Figure 7 corroborates the results presented above. The reason for this is that the estimate (red line) has a significant adjustment to the real value (black line).

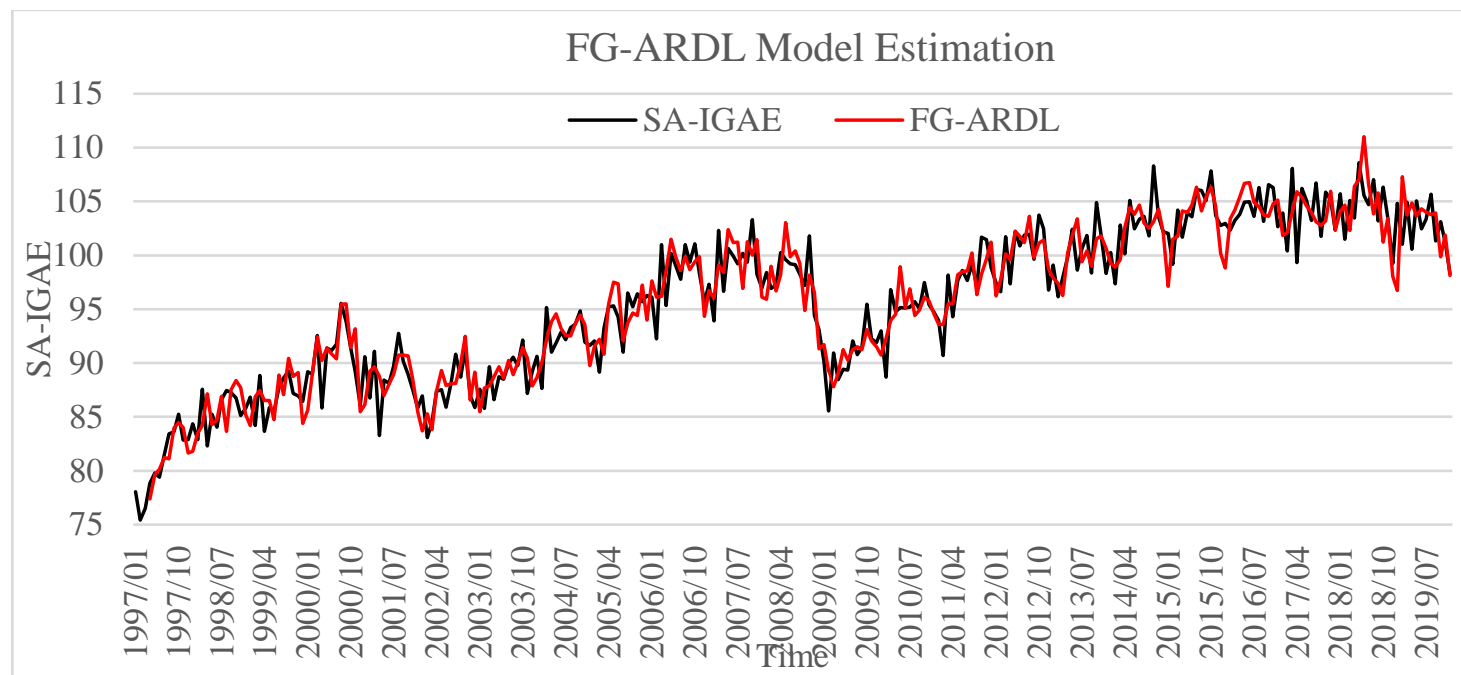

Figure 6. FG-ARDL model estimation for the Secondary Activities IGAE Source: Own elaboration in Excel and Eviews with data from INEGI.

The tertiary sector has a negative impact with the second lag, this is attributed to the seasonality of the time series, this depends strongly on the periods where the services market has a significant upward trend, denoting the influence of the seasonal component. The first effect to be highlighted in table 5 is that the total natural gas production $x_{10 t}$, in the ARDL model has a positive relationship with the TA-IAGAE, but the FG-ARDL model points out that this relationship is not positive, but rather, $x_{10 t}$ has an inverse relationship with an impact of -0.24 , therefore, we can see that the fuzzy model identified that the causality membership function among the variables indicates that the increase in natural gas production does not encourage the growth of tertiary economic activity and that this variable causes an inverse effect. The same effect can be seen in the variables $x_{24 t}, x_{25 t}$ and $x_{48 t}$, that change sign.

To corroborate the previous results, the variable volume of total domestic sales of other oil products $x_{22 t}$, has an inverse relationship with tertiary economic activity. These two models have the same sign and impact. One notable result is that petroleum products do not provide a positive effect on the economic growth of tertiary activity, except for fuels for land transport.

Table 5. Estimated parameters for the Tertiary Activities IGAE

\section{TA-IGAE}

\begin{tabular}{l|cc}
\hline $\begin{array}{l}\text { Ln(independent } \\
\text { variable) }\end{array}$ & $\begin{array}{c}\text { ARDL } \\
\text { parameter }\end{array}$ & $\begin{array}{c}\text { FG-ARDL }^{\circ} \\
\text { parameter }\end{array}$ \\
TA-IGAE (-2) & $-0.204200^{* * *}$ & $-0.191832 * * *$ \\
$\quad \boldsymbol{x}_{\mathbf{1 0}}$ & $0.211682 * * *$ & $-0.249631^{* * *}$ \\
\multicolumn{1}{c|}{$\boldsymbol{x}_{\mathbf{1 8}}$} & $0.145726 * * *$ & $0.011393 * * *$ \\
\hline
\end{tabular}




\begin{tabular}{c|lll|}
$\boldsymbol{x}_{\mathbf{2 2}}$ & $-0.016470^{* * *}$ & $-0.017086^{* * *}$ \\
$\boldsymbol{x}_{\mathbf{2 4}}$ & $0.174171^{* * *}$ & $-0.050533^{* * *}$ \\
$\boldsymbol{x}_{\mathbf{2 5}}$ & $0.081355^{* * *}$ & $-0.153215^{* * *}$ \\
$\boldsymbol{x}_{\mathbf{4 8}}$ & $0.000175^{* *}$ & $-0.000367 * *$ \\
$\boldsymbol{x}_{\mathbf{5 0}}$ & $-0.016943 * * *$ & $0.031149 * * *$ \\
$\boldsymbol{x}_{\mathbf{5 2}}$ & $0.000509 * *$ & $0.000455^{* *}$ \\
$\boldsymbol{x}_{\mathbf{5 3}}$ & $-0.021610^{* * *}$ & $0.0310454 * *$ \\
\hline $\begin{array}{l}\text { Note: Statistically significant at } 99 \%(* * *), 95 \%(* *) \text { and } 90 \%(*) \\
\text { o } \text { Fuzzy coefficients have the same level of statistical significance } \\
\text { as crisp coefficients. }\end{array}$ \\
\hline
\end{tabular}

Source: Own elaboration in Excel and Eviews with data from INEGI.

The volume of total domestic sales of PEMEX diesel $x_{18 t}$ has a direct relationship, or what can be interpreted as an increase in domestic diesel consumption causing an increase in tertiary economic activities, however, the fuzzy model (parameter of 0.01) indicates that this impact is less than the ARDL methodology captured in the coefficient of 0.14 . The above result is complemented by the change in sign observed in the volume of petrol imports $x_{52 t}$ has a positive relationship with the increase in the Global Economic Activity Indicator analyzed, the aspect that the ARDL model identified as an inverse relationship. In other words, fuels for land transport are the main source of energy that impulses the production in Mexico, a result that is supported by the results of the IGAE, SE-IGAE and TA-IGAE equation. The first important conclusion of this research is that the causal relationship between the energy sector and the growth of the Mexican economy is mainly in the diesel and gasoline variables, therefore, the increase in energy consumption of land transport is crucial to identify the importance of energy consumption for the positive impulse of the national economy.

On the other hand, the volume of liquefied gas imports and volume of fuel oil imports changed their sign, but contrary to the previous variables, these coefficients go from an inverse relationship to a direct one but maintaining the level of impact.

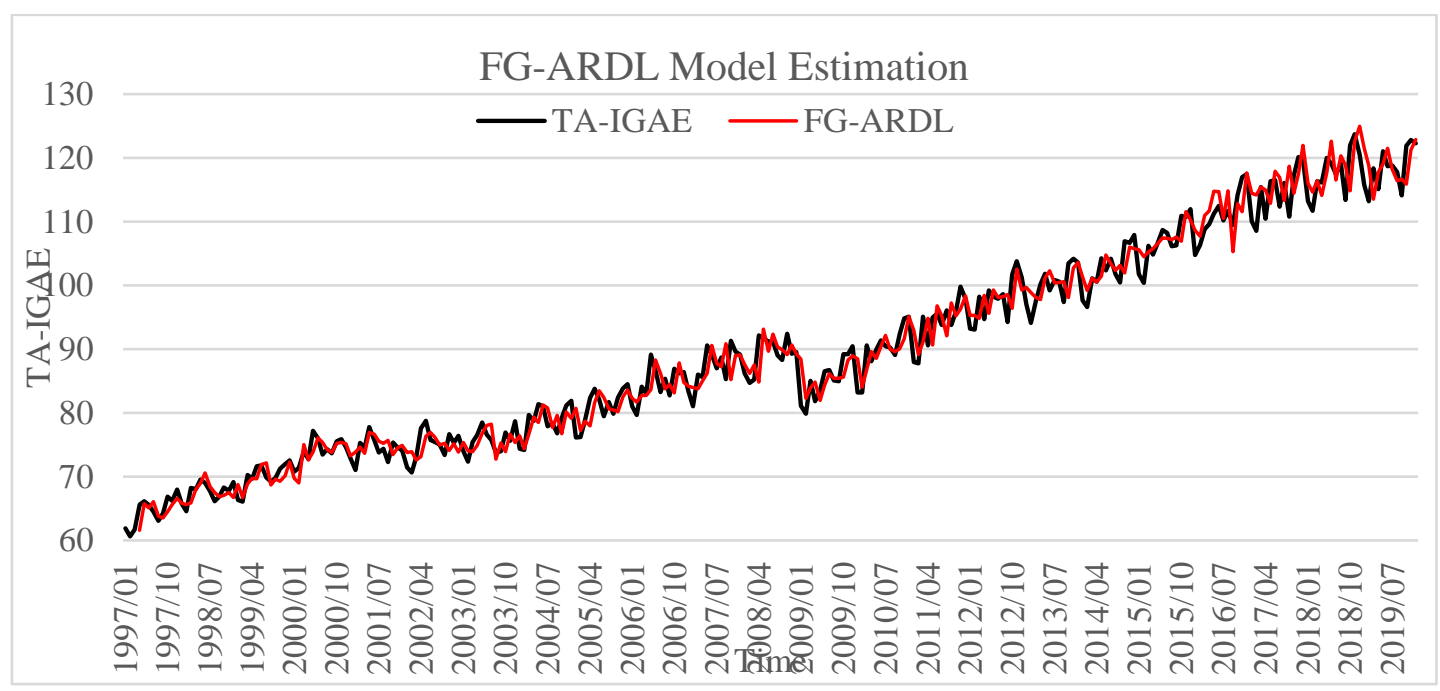

Figure 7. FG-ARDL model estimation for the Tertiary Activities IGAE Source: Own elaboration in Excel and Eviews with data from INEGI. 
Table 6 shows five tests to measure the efficiency of the estimated models, about the errors obtained by each methodology. The results for the four dependent variables analyzed are presented, and the method that obtained the best values in the tests per equation is highlighted. For instance, the tertiary economic activity has an absolute mean deviation of $1.7 \%$ less than the conventional ARDL methodology, the root of the mean square error has a $1 \%$ decrease in the fuzzy model and the Hannan-Quinn information criterion the FG-ARDL model is 300 points smaller than the traditional model, besides the errors of the proposed method are closer to following a normal distribution.

The central hypothesis of this research is to point out the importance of the variables of the oil sector for the growth of economic activity in Mexico. The results point out that energy sources for landbased machinery are those that show the greatest impact on economic activity.

Table 6. Results of the efficiency of the four variables estimated using two models

\begin{tabular}{|c|l|c|c|c|c|c|}
$\begin{array}{c}\text { Independent } \\
\text { variable }\end{array}$ & Model & $\begin{array}{c}\text { Mean absolute } \\
\text { deviation }\end{array}$ & $\begin{array}{c}\text { Root Mean } \\
\text { Square Error }\end{array}$ & $\begin{array}{c}\text { Hannan- } \\
\text { Quinn } \\
\text { Information } \\
\text { Criterion }\end{array}$ & $\begin{array}{c}\text { Jarque- } \\
\text { Bera }\end{array}$ & Kurtosis \\
\hline \multirow{2}{*}{ IGAE } & ARDL & $1.47 \%$ & $1.83 \%$ & -2138.42 & 4.4020 & 2.8556 \\
\hline \multirow{2}{*}{ PA-IGAE } & FG-ARDL & $1.40 \%$ & $1.76 \%$ & -2159.78 & 0.0985 & 3.0616 \\
\hline & ARDL & $11.80 \%$ & $14.55 \%$ & -1033.33 & 5.5606 & 2.6240 \\
\hline \multirow{2}{*}{ SA-IGAE } & FG-ARDL & $11.69 \%$ & $14.69 \%$ & -1027.77 & 3.7318 & 2.7900 \\
\hline \multirow{2}{*}{ TA-IGAE } & ARDL & $1.82 \%$ & $2.31 \%$ & -2041.06 & 258597.2 & 152.16 \\
\hline & FG-ARDL & $1.80 \%$ & $0.38 \%$ & -2049.74 & 0.6162 & 3.2285 \\
\hline & ARDL & $3.95 \%$ & $4.78 \%$ & -1632.80 & 4.2224 & 2.3961 \\
\hline & FG-ARDL & $2.21 \%$ & $3.78 \%$ & -1930.15 & 0.3151 & 2.9363 \\
\hline
\end{tabular}

Source: Own elaboration in Excel and Eviews with data from INEGI.

On the other hand, a specific comparison has been made between a common method for economic analysis, estimated through the population regression function, and a fuzzy theory methodology, estimated through a Gaussian linear optimization problem. The results indicate that the method of estimation by using membership functions identifies better the causal effects between economic variables, but also, presents a more adequate adjustment to the behavior of the variable studied, thus improving the adaptation to time series with high volatility as in the case of the variables analyzed.

The FG-ARDL model succeeds to capture important information for the economic analysis, based on a causal study that can incorporate improvement processes in the results, sustaining hypotheses that traditional linear models do not identify.

Therefore, to conclude with the present investigation, we have to consider from equation (7), the extraction of natural resources, energy consumption from fossil resources, domestic sales of energy derived from oil, imports, and exports impact on short-term economic growth; the evidence for the four estimated equations shows that these elements of the linear equation do explain economic growth, however, prices have not shown statistical significance for this research, an aspect that can be attributed to the fact that the explicative capacity of these variables is already captured by domestic sales, imports, and exports. 


\section{Conclusions and recommendations}

Economic growth is one of the main issues of analysis by economic researchers, and this research is no exception. We developed an analysis of the impact that the oil industry has on Mexico's economic growth. The results showed that there is a strong relationship between the oil industry and the economy, but this study examines in detail the impact of the main variables derived from oil activity. A total of 58, time series derived from the petroleum sector were studied, to examine the impact of each one on the short-term economic growth of the total economy, primary activities, secondary activities, and tertiary activities. As a result, 25 of the 58 variables were significant in the explanation of the economic growth of some of the economic sectors studied in the period analyzed.

Second, but no less important, we found that exists evidence in the present study that the FG-ARDL model achieves better estimates in of the impact coefficients for the explicative variables in the energy sector to the short term economic growth rate in the Mexican economy, this is sustained by the efficiency criteria in the model, such as Mean Absolute Deviation, Root of the Mean Square Error, Hannan-Quinn, and Jarque-Bera.

For instance, the mean absolute deviation results indicate that the fuzzy model is better than the traditional method because in the four estimated equations the value provided by the test is lower for the proposed model compared to the ARDL model. In the Root Mean Error, Hannan-Quinn, and Jarque-Bera test a significant statistical trend confirms the better results of the FG-ARDL model, compared to the ARDL equation.

The above is extremely relevant since we can say that the model FG-ARDL is more precise in the estimation process and are better adapted to studies of aggregated economic variables, consequently allowing for a better analysis of impact coefficients, making to establish causal relationships defined in a membership function. The mentioned function provides impact levels of one variable to another, indicating that the parameter can be modified according to the criterion of minimum error.

Therefore, the FG-ARDL model provides a more specific scenario for each time series, caused by a better estimation of the behavior of economic variables. A relevant result is that the parameter associated with each independent variable can oscillate around the mean parameter and three scenarios can be generated:

I. The first is that the coefficient is maintained at the same level or modified in a minimum proportion, suggesting that the fuzzy model identifies that the ARDL does capture the variable information.

II. The value of the coefficient varies significantly, increasing or decreasing the impact; this means that the FG-ARDL model points out that the traditional ARDL model does not correctly estimate the information of the variable.

III. Finally, the parameter changes sign, indicating that the fuzzy model identifies the causal relationship differently from the ARDL model; that is, the least error criterion provides information that linear regression analysis does not recognize.

Derived of the improvement in the FG-ARDL model fit, one of the main results of the present research was obtained, this is that the internal sales of the Pemex diesel are the main relevant impact for the aggregated economy in Mexico, this means, within the variety of petroleum products that are consumed domestically in the country, the Pemex diesel is the product that is recognized as the fundamental factor for the growth in the productive economic activity. 
Besides, the variables that do not display statistical significance for economic growth are mainly the extraction of fossil fuels by region or type and the prices of oil products, except for the American region.

\section{References}

[1] Aali-Bujari, A. F. Venegas-Martínez and A. O. Palafox-Roca (2017). Impact of Energy Consumption on Economic Growth in Major OECD Economies (1977-2014): A Panel Data Approach. International Journal of Energy Economics and Policy, Vol. 7, No. 2, pp. 1-8.

[2] Ahmad, M., Jabeen, G., Irfan, M., Mukeshimana, M. C., Ahmed, N., \& Jabeen, M. (2020). Modeling Causal Interactions Between Energy Investment, Pollutant Emissions, and Economic Growth: China Study. Biophysical Economics and Sustainability, 1-12. doi:https://doi.org/10.1007/s41247-019-0066-7

[3] Algarini, A. (2020). The Relationship among GDP, Carbon Dioxide Emissions, Energy Consumption, and Energy Production from Oil and Gas in Saudi Arabia. International Journal of Energy Economics and Policy, 10(1), 280-285. doi:https://doi.org/10.32479/ijeep.8345

[4] Antón, J. I., \& Padilla, F. L. (2015). La viabilidad del Presupuesto Base Cero como alternativa para ejercer con eficiencia el gasto público en México. El Cotidiano, 93-102. Obtenido de https://www.redalyc.org/pdf/325/32539883012.pdf

[5] Appiah, M. O. (2018). Investigating the multivariate Granger causality between energy consumption, economic growth and CO2 emissions in Ghana. Energy Policy, 198-20. doi:http://dx.doi.org/10.1016/j.enpol.2017.10.017

[6] Barro, R. J., \& Sala-i-Martin, X. (2018). Crecimiento económico. Reverte.

[7] Bekhet, H. A., Matar, A., \& Yasmin, T. (2017). CO2 emissions, energy consumption, economic growth, and financial development in GCC countries: Dynamic simultaneous equation models. Renewable and Sustainable Energy Reviews, 117-132. doi:https://doi.org/10.1016/j.rser.2016.11.089

[8] Churchill, S. A., \& Ivanovski, K. (2019). Electricity consumption and economic growth across Australian states and territories. Applied Economics. doi:https://doi.org/10.1080/00036846.2019.1659932

[9] Dabachi, U. M., Mahmood, S., Ahmad, A. U., Ismail, S., Farouq, I. S., Jakada, A. H., . . Kabiru, K. (2020). Energy Consumption, Energy Price, Energy Intensity Environmental Degradation, and Economic Growth Nexus in African OPEC Countries: Evidence from Simultaneous Equations Models. Journal of Environmental Treatment Techniques, 403-409.

[10] Domar, E. D. (1946). Capital expansion, rate of growth and employment. Econometrica, 14, pp.137-147, doi:10.2307/1905364

[11] Esso, L. J., \& Keho, Y. (2016). Energy consumption, economic growth, and carbon emissions: Cointegration and causality evidence from selected African countries. Energy, 492-497. doi:http://dx.doi.org/10.1016/j.energy.2016.08.010

[12] Galadima, M. D., \& Aminu, A. W. (2019). Nonlinear unit root and nonlinear causality in natural gas economic growth nexus: Evidence from Nigeria. Energy. doi:https://doi.org/10.1016/j.energy.2019.116415

[13] Habib-ur-Rahman, Ghazali, A., Bhatti, G. A., \& Khan, S. U. (2020). Role of Economic Growth, Financial Development, Trade, Energy and FDI in Environmental Kuznets Curve for Lithuania: Evidence from ARDL Bounds Testing Approach. Inzinerine Ekonomika-Engineering Economics,, 31(1), 39-49. doi:http://dx.doi.org/10.5755/j01.ee.31.1.22087

[14] Harrod, R. (1939). An Essay in dynamic theory. Economic Journal. 49, 14-33, doi:10.2307/2225181.

[15] Kaldor, N. (1960), Essays in Value and Distribution, Duckworth, London. https://doi.org/10.2307/2601416 
[16] Khan, M. K., Khan, M. I., \& Rehan, M. (2020). The relationship between energy consumption, economic growth and carbon dioxide emissions in Pakistan. Financial Innovation, 1-13. doi:https://doi.org/10.1186/s40854-019-0162-0

[17] Khobai, H. (2017). Electricity consumption and Economic growth: A panel data approach to Brics countries. Munich Personal RePEc Archive. Obtenido de https://mpra.ub.uni-muenchen.de/82460/

[18] Koondhar, M. A., Li, H., Wang, H., Bold, S., \& Kong, R. (2020). Looking back over the past two decades on the nexus between air pollution, energy consumption, and agricultural productivity in China: a qualitative analysis based on the ARDL bounds testing model. Environmental Science and Pollution Research, 1-15. doi:https://doi.org/10.1007/s11356-019-07501-z

[19] Le, T.-H., Chang, Y., \& Park, a. D. (2020). Renewable and Nonrenewable Energy Consumption, Economic Growth, and Emissions: International Evidence. The Energy Journal, 41(2). doi:https://doi.org/10.5547/01956574.41.2.thle

[20] Marroquín-Arreola, J., \& Ríos-Bolívar, H. (2017). Crecimiento económico, precios y consumo de energía en México. Ensayos Revista de Economía, 59-78. https://doi.org/10.29105/ensayos36.1-3

[21] Meade, J. (1978). The Meaning of "Internal Balance", The Economic Journal, 88 (351): 423-435, doi: $10.2307 / 2232044$

[22] Miranda-Mendoza, N. (2015). El Presupuesto Base Cero como disciplina para una mejor inversión pública en México. El Cotidiano, 103-109. Obtenido de https://www.redalyc.org/pdf/325/32539883013.pdf

[23] Mirza, F. M., \& Kanwal, A. (2017). Energy consumption, carbon emissions and economic growth in Pakistan: Dynamic causality analysis. Renewable and Sustainable Energy Reviews, 1233-1240. doi:http://dx.doi.org/10.1016/j.rser.2016.10.081

[24] Nadeem, A. M., Ali, T., Khan, M. T., \& Guo, Z. (2020). Relationship between inward FDI and environmental degradation for Pakistan: an exploration of pollution haven hypothesis through ARDL approach. Environmental Science and Pollution Research. doi:https://doi.org/10.1007/s11356-020-08083-x

[25] Nguyen, H. M., \& Ngoc, B. H. (2020). Energy Consumption - Economic Growth Nexus in Vietnam: An ARDL Approach with a Structural Break. Journal of Asian Finance, Economics and Business, 7(1), 101110. doi:doi:10.13106/jafeb.2020.vol7.no1.101

[26] Nweze, N. P., \& Edame, G. E. (2016). An EmpiricalInvestigation of Oil Revenue and Economic Growth in Nigeria. European Scientific Journal, 271-294. doi: 10.19044/esj.2016.v12n25p271

[27] Razmi, S. F., Bajgiran, B. R., Behname, M., Salari, T. E., \& Razmi, S. M. (2020). The relationship of renewable energy consumption to stock market development and economic growth in Iran. Renewable Energy, 145, 2019-2024. https://doi.org/10.1016/j.renene.2019.06.166

[28] Robinson, J. (1962). Un modelo de acumulación. Economía PosKeynesiana. Fondo de Cultura.

[29] Robinson, J. (1963). Essays in the Theory of Economic Growth London: Macmillan \& Co. Ltd. https://doi.org/10.1007/978-1-349-00626-7

[30] Sadeghi, M., \& Hosseini, H. M. (2006). Energy supply planning in Iran by using fuzzy linear programming approach (regarding uncertainties of investment costs). Energy Policy, 993-1003. doi:10.1016/j.enpol.2004.09.005

[31] Sala-i-Martin. (2000). Apuntes de crecimiento económico. Antoni Bosch Editor.

[32] Salazar-Núñez, H. F., F. Venegas-Martínez, and M. Á. Tinoco-Zermeño (2020). Impact of Energy Consumption and Carbon Dioxide Emissions on Economic Growth: Cointegrated Panel Data in 79 Countries Grouped by Income Level. International Journal of Energy Economics and Policy, Vol. 10, No. 2, pp. 218-226. https://doi.org/10.32479/ijeep.8783

[33] Santillán-Salgado, R. J. and F. Venegas-Martínez (2016). Impact of Oil Prices on Economic Growth in Latin American Oil Exporting Countries (1990-2014): A Panel Data Analysis. Journal of Applied Economic Sciences. Vol. 11, No. 4(42), pp. 672-684. https://doi.org/10.2139/ssrn.2692024 
[34] Siddiqui, R. (2004). Energy and Ecomomic Growth in Pakistan. The Pakistan Development Review, 172200. https://doi.org/10.30541/v43i2pp.175-200

[35] Solarin, S. A., \& Ozturk, I. (2016). The relationship between natural gas consumption and economic growth in OPEC members. Renewable and Sustainable Energy Reviews, 1348-1356. doi:https://doi.org/10.1016/j.rser.2015.12.278

[36] Solow, R.M., (1956), A Contribution to the Theory ofEconomic Growth, Quarterly Journal of Economics, $70,65-94$.

[37] Suganthi, L., Iniyan, S., \& Samuel, A. A. (2019). Factors Affecting Energy Consumption in the Agricultural Sector of Iran: The Application of ARDL-FUZZY. International Journal of Agricultural Management and Development, 293-305.

[38] Sunde, T. (2020). Energy consumption and economic growth modelling in SADC countries: an application of the VAR Granger causality analysis. International Journal Energy Technology and Policy, 41-56. https://doi.org/10.1504/ijetp.2020.10025312

[39] Tang, X., Deng, H., Zhang, B., Snowden, S., \& Höök, M. (2016). Nexus Between Energy Consumption and Economic Growth in China: From the Perspective of Embodied Energy Imports and Exports. Emerging Markets Finance and Trade, 1298-1304. doi:10.1080/1540496X.2016.1152791

[40] Tiba, S., \& Omri, A. (2017). Literature survey on the relationships between energy, environment and economic growth. Renewable and Sustainable Energy Reviews, 1129- 1146. doi:http://dx.doi.org/10.1016/j.rser.2016.09.113

[41] Zhang, B., Wang, Z., \& Wang, B. (2018). Energy production, economic growth and CO 2 emission: evidence from Pakistan. Natural Hazards, 90(1), 27-50. doi:10.1007/s11069-017-3031-z

\section{Anexes}

Table A7. KPSS Unit Root Test

\begin{tabular}{|c|l|l|l|l|}
\hline VariablelKPSS test & Levels & $\begin{array}{c}\text { First } \\
\text { Difference } \\
\text { Probability }\end{array}$ & $\begin{array}{c}\text { Second } \\
\text { Difference }\end{array}$ & Integration Order \\
\hline IGAE & 0.9088 & 0.0021 & 0.0000 & First Order \\
\hline PA-IGAE & 0.9656 & 0.0000 & 0.0000 & First Order \\
\hline SA-IGAE & 0.4346 & 0.0037 & 0.0000 & First Order \\
\hline TA-IGAE & 0.4915 & 0.0045 & 0.0000 & First Order \\
\hline $\boldsymbol{Y}_{\mathbf{5} \boldsymbol{t}}$ & 0.9370 & 0.0059 & 0.0000 & First Order \\
\hline $\boldsymbol{x}_{\mathbf{1}}$ & 0.9994 & 0.0000 & 0.0000 & First Order \\
\hline $\boldsymbol{x}_{\mathbf{2} \boldsymbol{t}}$ & 0.9895 & 0.0000 & 0.0000 & First Order \\
\hline $\boldsymbol{x}_{\mathbf{3} \boldsymbol{t}}$ & 0.9998 & 0.0000 & 0.0000 & First Order \\
\hline $\boldsymbol{x}_{\mathbf{4} \boldsymbol{t}}$ & 0.9645 & 0.0000 & 0.0000 & First Order \\
\hline $\boldsymbol{x}_{\mathbf{5} \boldsymbol{t}}$ & 0.8420 & 0.0000 & 0.0000 & First Order \\
\hline $\boldsymbol{x}_{\mathbf{6} \boldsymbol{t}}$ & 0.5996 & 0.0000 & 0.0000 & First Order \\
\hline $\boldsymbol{x}_{\mathbf{7} \boldsymbol{t}}$ & 0.9976 & 0.0000 & 0.0000 & First Order \\
\hline $\boldsymbol{x}_{\mathbf{8} \boldsymbol{t}}$ & 0.9920 & 0.0000 & 0.0000 & First Order \\
\hline $\boldsymbol{x}_{\mathbf{9} \boldsymbol{t}}$ & 0.7903 & 0.0000 & 0.0000 & First Order \\
\hline & & & & \\
\hline
\end{tabular}




\begin{tabular}{|c|c|c|c|c|}
\hline VariablelKPSS test & Levels & $\begin{array}{c}\text { First } \\
\text { Difference } \\
\text { Probabilit }\end{array}$ & $\begin{array}{c}\text { Second } \\
\text { Difference }\end{array}$ & Integration Order \\
\hline$x_{10 t}$ & 0.6154 & 0.0000 & 0.0000 & First Order \\
\hline$x_{11 t}$ & 0.4406 & 0.0000 & 0.0000 & First Order \\
\hline$x_{12 t}$ & 0.8525 & 0.0000 & 0.0000 & First Order \\
\hline$x_{13 t}$ & 0.9583 & 0.0000 & 0.0000 & First Order \\
\hline$x_{14 t}$ & 0.2918 & 0.0000 & 0.0000 & First Order \\
\hline$x_{15 t}$ & 0.7960 & 0.0000 & 0.0000 & First Order \\
\hline$x_{16 t}$ & 0.9976 & 0.0000 & 0.0000 & First Order \\
\hline$x_{17 t}$ & 0.9012 & 0.0260 & 0.0000 & First Order \\
\hline$x_{18 t}$ & 0.7399 & 0.4759 & 0.0000 & Second Order \\
\hline$x_{19 t}$ & 0.1024 & 0.0001 & 0.0000 & First Order \\
\hline$x_{20 t}$ & 0.9697 & 0.0000 & 0.0000 & First Order \\
\hline$x_{21 t}$ & 0.0009 & 0.0000 & 0.0000 & Levels \\
\hline$x_{22 t}$ & 0.4244 & 0.0000 & 0.0000 & First Order \\
\hline$x_{23 t}$ & 0.2448 & 0.0000 & 0.0000 & First Order \\
\hline$x_{24 t}$ & 0.2855 & 0.0005 & 0.0000 & First Order \\
\hline$x_{25 t}$ & 0.1648 & 0.0003 & 0.0000 & First Order \\
\hline$x_{26 t}$ & 0.2817 & 0.0018 & 0.0000 & First Order \\
\hline$x_{27 t}$ & 0.4545 & 0.0000 & 0.0000 & First Order \\
\hline$x_{28 t}$ & 0.0156 & 0.0000 & 0.0000 & First Order \\
\hline$x_{29 t}$ & 0.1563 & 0.0000 & 0.0000 & First Order \\
\hline$x_{30 t}$ & 0.4257 & 0.0000 & 0.0000 & First Order \\
\hline$x_{31 t}$ & 0.4959 & 0.0000 & 0.0000 & First Order \\
\hline$x_{32 t}$ & 0.3661 & 0.0000 & 0.0000 & First Order \\
\hline$x_{33 t}$ & 0.3581 & 0.0000 & 0.0000 & First Order \\
\hline$x_{34 t}$ & 0.3290 & 0.0000 & 0.0000 & First Order \\
\hline$x_{35 t}$ & 0.3246 & 0.0000 & 0.0000 & First Order \\
\hline$x_{36 t}$ & 0.4975 & 0.0000 & 0.0000 & First Order \\
\hline$x_{37 t}$ & 0.3581 & 0.0000 & 0.0000 & First Order \\
\hline$x_{38 t}$ & 0.8384 & 0.0000 & 0.0000 & First Order \\
\hline$x_{39 t}$ & 0.2318 & 0.0000 & 0.0000 & First Order \\
\hline$x_{40 t}$ & 0.3436 & 0.0000 & 0.0000 & First Order \\
\hline$x_{41 t}$ & 0.0000 & 0.0000 & 0.0000 & First Order \\
\hline$x_{42 t}$ & 0.0618 & 0.0000 & 0.0000 & First Order \\
\hline$x_{43 t}$ & 0.4482 & 0.0000 & 0.0000 & First Order \\
\hline$x_{44 t}$ & 0.0001 & 0.0000 & 0.0000 & Levels \\
\hline$x_{45 t}$ & 0.8275 & 0.0000 & 0.0000 & First Order \\
\hline$x_{46 t}$ & 0.0248 & 0.0000 & 0.0000 & Levels \\
\hline$x_{47 t}$ & 0.0423 & 0.0000 & 0.0000 & Levels \\
\hline$x_{48 t}$ & 0.0005 & 0.0000 & 0.0000 & Levels \\
\hline
\end{tabular}


REMEF (The Mexican Journal of Economics and Finance)

Short-Term Causal Relationships between the Oil Sector and Economic

Growth in the Mexican Economy: FG-ARDL Approach

\begin{tabular}{|l|l|l|l|l|}
\hline VariablelKPSS test & Levels & $\begin{array}{c}\text { First } \\
\text { Difference } \\
\text { Probability }\end{array}$ & $\begin{array}{c}\text { Second } \\
\text { Difference }\end{array}$ & \multicolumn{1}{|c|}{ Integration Order } \\
\hline $\boldsymbol{x}_{\mathbf{4 9 t}}$ & 0.3970 & 0.0000 & 0.0000 & First Order \\
\hline $\boldsymbol{x}_{\mathbf{5 0 t}}$ & 0.0722 & 0.0000 & 0.0000 & First Order \\
\hline $\boldsymbol{x}_{\mathbf{5 1 t}}$ & 0.4107 & 0.0000 & 0.0000 & First Order \\
\hline $\boldsymbol{x}_{\mathbf{5 2 t}}$ & 0.3625 & 0.0000 & 0.0000 & First Order \\
\hline $\boldsymbol{x}_{\mathbf{5 3 t}}$ & 0.0000 & 0.0000 & 0.0000 & Levels \\
\hline $\boldsymbol{x}_{\mathbf{5 4 t}}$ & 0.0689 & 0.0000 & 0.0000 & First Order \\
\hline $\boldsymbol{x}_{\mathbf{5 5 t}}$ & 0.9205 & 0.0000 & 0.0000 & First Order \\
\hline $\boldsymbol{x}_{\mathbf{5 6 t}}$ & 0.6335 & 0.0000 & 0.0000 & First Order \\
\hline $\boldsymbol{x}_{\mathbf{5 7 t}}$ & 0.4271 & 0.0000 & 0.0000 & First Order \\
\hline & Source: Own elaboration in Eviews with data from INEGI. \\
\hline
\end{tabular}

Table A8. Statistics for the dependent variables

\begin{tabular}{|c|c|c|c|c|}
\hline Statistics & IGAE & PA-IGAE & SA-IGAE & TA-IGAE \\
\hline Mean & 0.001922 & 0.002616 & 0.000838 & 0.002474 \\
\hline Median & -0.003144 & -0.021062 & -0.001675 & -0.001943 \\
\hline Maximum & 0.079639 & 0.523699 & 0.090413 & 0.084929 \\
\hline Minimum & -0.079221 & -0.385729 & -0.089663 & -0.099079 \\
\hline Std. Dev. & 0.030561 & 0.183095 & 0.032514 & 0.033081 \\
\hline Skewness & 0.4336 & 0.548986 & 0.179606 & 0.1412 \\
\hline Kurtosis & 2.59 & 2.67 & 2.96 & 2.86 \\
\hline Jarque-Bera & 10.48 & 15.05 & 1.48 & 1.11 \\
\hline
\end{tabular}

Source: Own elaboration in Eviews with data from INEGI. 